\title{
RAW MATERIAL STUDY OF THE MOUSTERIAN LITHIC ASSEMBLAGE OF NAVALMAÍllo ROCKSHELTER (PINILLA DEL VALLE, SPAIN): PRELIMINARY RESULTS
}

\author{
A. Abrunhosa ${ }^{(1)}$, B. MÁrquez ${ }^{(2)}$, E. Baquedano $^{(3)}$, N. Bicho $^{(4)}$, A. PÉreZ-GonZÁlez $^{(5)} \&$ J. L. ArsuagA ${ }^{(6)}$
}

\begin{abstract}
:
This article presents the $\mathrm{PhD}$ project under the supervision of Nuno Bicho and Enrique Baquedano, which aims to study the origin of raw materials from the Mousterian lithic sets of the Calvero de la Higuera sites. At this first stage of the project the main objective is the determination and characterization of the raw materials present at the sites.

Keywords: Middle Paleolithic, Lithics, Raw Material Procurement, Navalmaillo rockshelter, Neanderthals

Resumo:

Estudo das matérias-primas da indústria lítica Moustierense do Abrigo de Navalmaíllo (Pinilla del Valle, Espanha): resultados preliminares

O presente artigo apresenta o projecto de doutoramento, sob a orientação de Nuno Bicho e Enrique Baquedano, que visa o estudo da proveniência das matérias-primas dos conjuntos líticos moustierenses do Calvero de la Higuera (Pinilla del Valle, Madrid - Espanha). Nesta primeira etapa do projecto, o objectivo principal é a determinação e caracterização das matérias-primas presentes nas colecções líticas.
\end{abstract}

Palavras-chave: Paleolítico Médio, Líticos, Proveniência de matérias-primas, Abrigo de Navalmaíllo, Neanderthais.

\section{INTRODUCTION}

Analyses of behaviour and cognitive abilities of prehistoric groups have been conceptualized through technological studies and sources of raw materials. Even though the Iberian Peninsula has a considerable number of sites and sequences from the Medium and Early Upper Pleistocene (TORRE et al. 2014), most Middle Palaeolithic sites are located in coastal regions. This can be due to a focus of research and studies in these areas (PEREIRA 2013; PEREIRA et al. 2014) and a lack of survey in the central Peninsula but also because of the geographical and geological characteristics of the Meseta area.

The Iberian Peninsula is a prime location for the study of the Middle Palaeolithic. It was in Iberia that, for the last time in the history of humankind, two human species coexisted for a longer period than in the rest of Europe - Homo neanderthalensis and Homo sapiens sapiens and the former became extinct in a particularly late stage (FINLAYSON et al. 2006).

The ongoing project of the study of lithic raw materials from a site of this chronology in the centre of the Iberian Peninsula will provide a much broader knowledge of the relationship with the territory explored by Neanderthals in the Lozoya Valley (Pinilla del Valle - Madrid) and will allow a deeper understanding of its use and impact in this ecological niche. Through the study of the raw materials from the Mousterian sites of Pinilla del Valle and the technological behaviour of these populations we hope to contribute to the understanding of the territory of exploitation, settlement patterns and cognitive abilities.

2. ARCHAEOLOGICAL SITES OF THE CALVERO DE LA HIGUERA

\subsection{Geological and geographical context}

The archaeological sites of Pinilla del Valle are located in a limestone hill called Calvero de la Higuera in the upper Lozoya valley in the Guadarrama Sierra (Community of Madrid Spain) at a distance of c. $90 \mathrm{~km}$ north from the city of Madrid (Fig.1).

The Upper valley of the Lozoya River is a pop-down structure formed during the Alpine Orogeny with an elevation of 1100 metres at the Pinilla dam, within the pop-up of the Guadarrama Sierra which belongs to the NE-SW Spanish

\footnotetext{
(1) Universidade do Algarve, Núcleo de Arqueologia e Paleoecologia. ana.abrunhosa@gmail.com

${ }^{(2)}$ Museo Arqueológico Regional, Madrid. belen.marquez@madrid.org

${ }^{(3)}$ Museo Arqueológico Regional, Madrid. enrique.baquedano@madrid.org

${ }^{(4)}$ Universidade do Algarve, Núcleo de Arqueologia e Paleoecologia. nbicho@ualg.pt

${ }^{(5)}$ Centro Nacional de Investigación sobre la Evolución Humana (CENIEH), Burgos. alfredo.perez@cenieh.es

${ }^{(6)}$ Centro Mixto UCM-ISCIII de Evolución y Comportamiento Humanos, Madrid. jlarsuaga@isciii.es
} 
Central Range (BELlido et al. 1991; PÉREZ GONZÁlez et al. 2010; ARSUAGA et al. 2012). The north border is formed by the Carpetano Mountains (Montes Carpetanos) with the highest peak in Peñalara $(2428 \mathrm{~m})$ and the south border by Cuerda Larga Mountains with the highest point in Cabeza de Hierro $(2380 \mathrm{~m})$. The Upper valley is mainly situated within the shalegreywacke complex of Central Iberian Zone, with deformed and metamorphosed Proterozoic to Carboniferous rocks and different types of granitoids (VERA 2004). "The oldest rock outcrops consists of orthogneisses, leucogranites, adamellites, granitoids, migmatites and to a lesser degree schists and quartzites" (ARSUAGA et al.
2012:56) with also the presence of lamprophyres, porphyries and late quartzite dykes (PÉREZ GONZÁlez et al. 2010; ARSUAGA et al. 2012).

The Calvero de la Higuera is a hill composed by karst cavities developed in the slope of carbonated rocks from the Cretaceous and eroded by the Lozoya River and the two affluent streams of Lontanar and Valmaíllo that left three of the known sites in a hanging geological position (PÉREZ GONZÁlEZ et al. 2010; Arsuaga et al. 2012). The karst in the Calvero formed caves and shelters used by both man and animals from Middle Pleistocene until the beginnings of the Holocene.

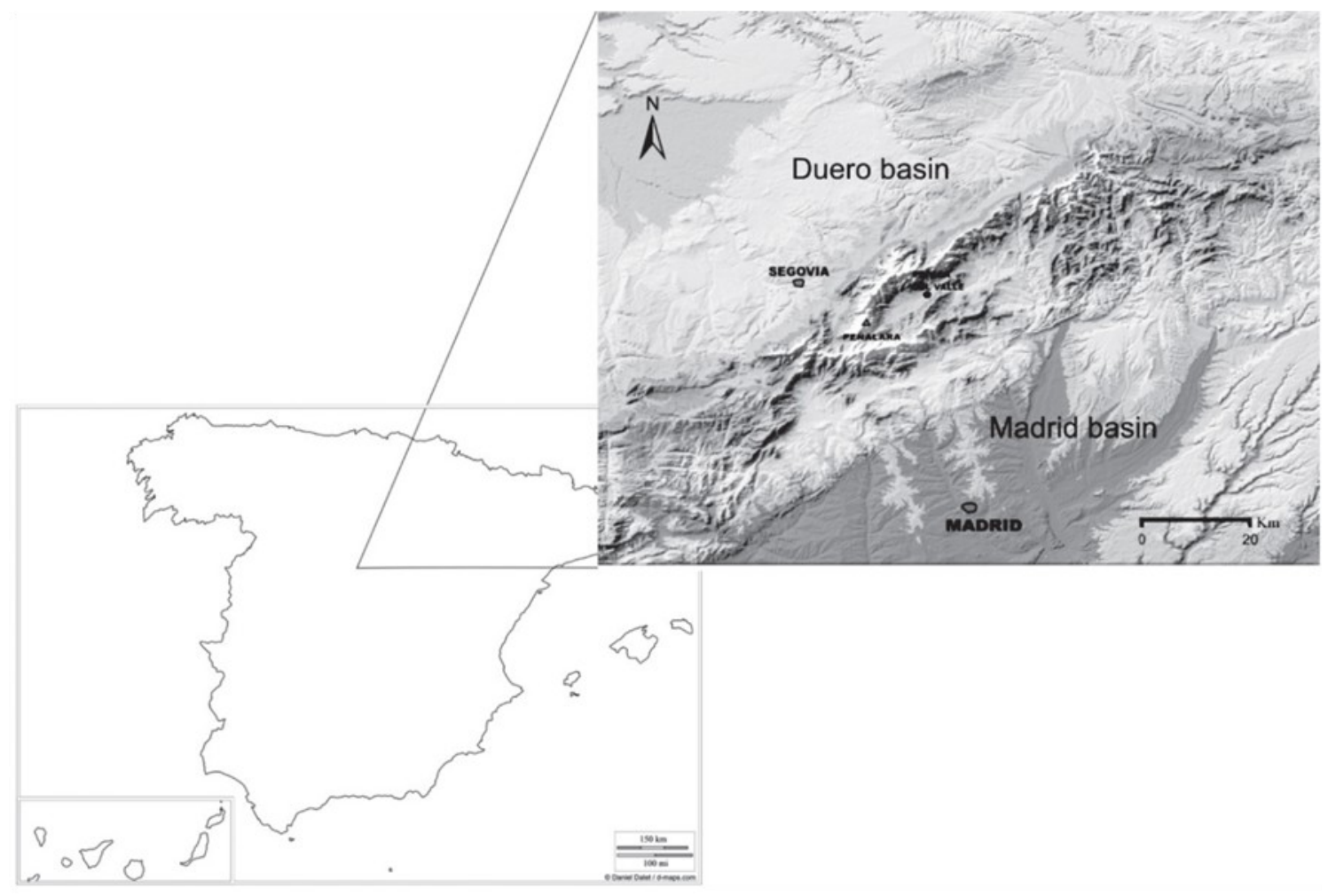

Fig. 1. Location of the archaeological sites in Pinilla del Valle in the Valley of Lozoya River (Sierra de Guadarrama). In Marquez 2013.

Fig. 1. Localização dos sítios arqueológicos de Pinilla del Valle no Vale do rio Lozoya (Serra de Guadarrama). In Marquez 2013.

\subsection{The archaeological sites}

In 1979 the first team of researchers that discovered the Pinilla del Valle sites, directed by Francisco Alférez, found Camino Cave (Cueva del Camino). Excavations were carried out in the beginnings of 1980 and first published in 1982 (ALFÉREZ 1982). A hiatus in the investigation of the Calvero de la Higuera sites occurred during the 1990's. Since 2002 the project has been directed by an interdisciplinary team with J. L. Arsuaga, E. Baquedano and A. Pérez-González as co -directors. From then-onward four more sites have been discovered: Navalmaíllo Rockshelter, Buena Pinta Cave, Des-Cubierta Cave and Ocelado Rockshelter. On the other hand, excavations are held for one month each year by an interdisciplinary team comprised of both volunteered students and researchers linked to this or other projects that contribute with their expertise (Fig.2). 


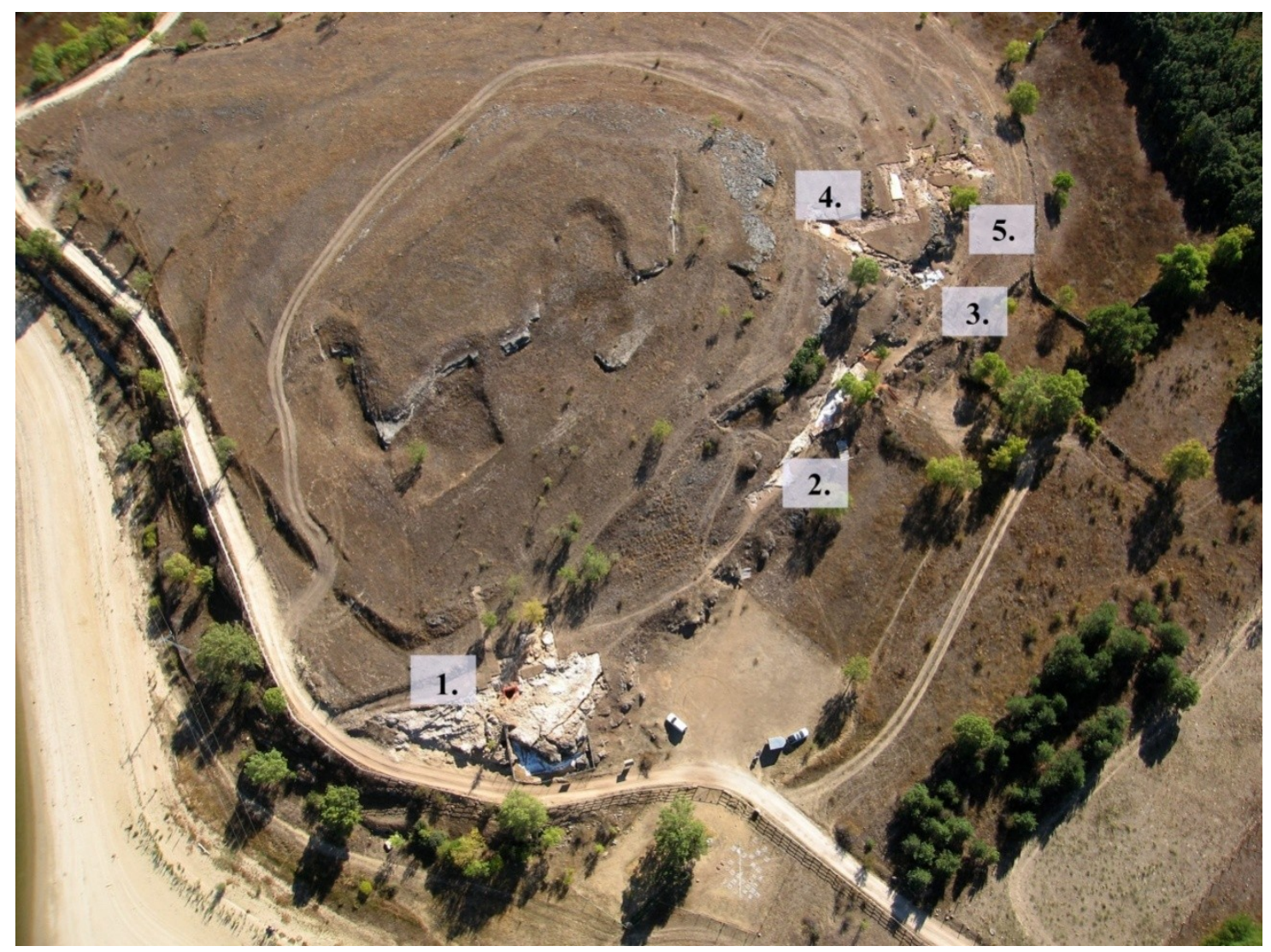

Fig. 2. Aerial photograph of the Calvero de la Higuera hill indicating the location of the archaeological sites: 1 - Camino Cave, 2 Navalmaíllo Rochskelter, 3 - Buena Pinta Cave, 4 - Des-cubierta Cave, 5 - Ocelado Rockskelter.

Fig. 2. Fotografia aérea do Calvero de la Higuera com indicação dos sítios arqueológicos: 1 - Cueva del Camino, 2 - Abrigo de Navalmaíllo, 3 - Cueva de la Buena Pinta, 4 - Cueva Des-cubierta, 5 - Abrigo del Ocelado.

\subsubsection{Camino Cave}

Camino Cave (Cueva del Camino) was discovered in 1979 (ALFÉREZ 1982) and the first excavations started in 1981 and ended in 1989 (ALFÉREZ \& ROLDÁN 1992). In 2002 the new team continued investigations being the last campaign in Camino Cave in 2009. The site is a cavity filled with sediments with roof falls on top 11 meters above the Lozoya River level and 6 to 7 meters from the bottom of the Lontanar stream. Due to erosion it is difficult for geologists to understand whereas it was a cave or a shelter (PÉREZ GONZÁLEZ et al. 2010). Characterized by a large accumulation of fossilized remains of small and large vertebrates and two human teeth identified as Homo neanderthalensis, Camino Cave represents one of the most complete MIS 5 records of the Iberian Peninsula (ARSUAGA et al. 2010, 2012). Level 5, where most of the animal remains were recovered, has a TL date of $90.961 \pm 7.881 \mathrm{ka}$ B.P. (PÉreZ GonZÁlez et al. 2010).

Though it was at first interpreted as a human occupation (ALFÉREZ 1982; ALFÉREZ et al. 1985; ALFÉREZ \& ROLDÁN 1992), there is an important presence of carnivores and no evidence of fire, cut marks on bone surface and very few lithic industry.
That is why it is more likely that Camino Cave was used as a hyena den (DíEz 1993; AlVAREZ-LAO et al. 2013; ARSUAGA et al. 2012).

\subsubsection{Navalmaíllo Rockshelter}

The fluvial activity of the Valmaíllo stream eroded the Late Cretaceous dolomites at the slope of the Calvero de la Higuera hill forming the Navalmaíllo Rockshelter (Abrigo de Navalmaíllo) at an elevation of c. 100 metres south from Camino Cave and 8 metres above the Lontanar stream (PÉREZ GONZÁLEZ et al. 2010; ARSUAGA et al. 2012; MÁRQUEZ et al. 2013).

When discovered in 2002, the site was partially covered by colluviums and detachments of the rock roof that collapsed after its abandonment (ARSUAGA et al. 2011). Excavation is currently still under way. The rock shelter occupies an area of c. $300 \mathrm{~m}^{2}$ confirmed by geological surveys in 2006 (PÉREZ GONZÁLEZ et al. 2010), and at least six levels $(\alpha, \beta, \gamma, \mathrm{D}, \mathrm{F}$ and $\mathrm{H})$ with abundant Mousterian industry. These levels also contain faunal remains with evidences of cut marks, burned bones and hearths. From level F two TL dates have been obtained ranging from $71.6 \pm 5.0$ to $77.2 \pm 6.0 \mathrm{ka}$ BP which indicates MIS 5a or early 
MIS 4, documenting an important Middle Palaeolithic occupation by Neanderthals (ARSUAGA et al. 2011; MÁRQUEZ et al. 2013).

The materials of different nature from this site are currently under study. The study of the paleontological record is still fragmentary but "the most abundant macro-mammal remains correspond to various species of herbivores" (ARSUAGA et al. 2011:117). A small group of carnivores is also present as are micro-mammals of the Mediterranean pine vole. An important feature of the set of animal bones from the $\mathrm{F}$ level is their high fragmentation. A preliminary study on the lithic industry focusing on quartz based industry was recently published (MÁRQUEZ et al. 2013). It was concluded that "quartz was the most commonly used raw material in tool-making at Navalmaíllo". Small pieces are abundant and were intentionally made (MÁRQUEZ et al. 2013:391). The study of the raw materials involved in the knapping of the lithic assemblage of this site will be developed in the following pages.

\subsubsection{Buena Pinta Cave}

The Buena Pinta Cave site, discovered in 2003, is located $80-90$ metres south from Navalmaíllo rockshelter and 9-10 metres above the Valmaíllo stream. The gallery is of phreatic origin with and elliptical section of 1.5 metres in the widest point and of 1 metre at its narrowest point. It has a known length of 10 metres (BAQUEDANO et al. 2010; PÉREZ GONZÁLEZ et al. 2010). A deposit of colluvium of the Holocene of c. 1.80 metres thick covered the entrance of the cave and the chronology obtained by 14C AMS (2 sigma), places that deposit between 5.740-5.610 and 1.940-1.800 cal. BP (RUIZ ZAPATA et al. 2008). The sediments that fill the gallery have been dated by TL on its higher layers (level 3) and place them in $63.4 \pm 5.5 \mathrm{ka} \mathrm{BP}$, i.e., in MIS 4 (PÉREZ GONZÁLEZ et al. 2010).

The excavations have been carried out since 2003 and further studies are still being conducted since "the understanding of the stratigraphic sequence of this site is still insufficient" (ARSUAGA et al. 2011:117). One of the main characteristics of this site is the large quantity of faunal remains, both micro and macro are similar to the ones found in Camino Cave. Their study permitted to understand the site and it is known now that during the Upper Pleistocene this cave was mostly used as a hyena den (Crocuta crocuta). The recent taphonomic analyses revealed anthropic activity. There is also a small number of lithic industry present in some levels still under study that allow to forward the idea that human groups could have temporarily occupied the cavity, competing with big mammals (ARSUAGA et al. 2011; BAQUEDANO et al. 2010, 2014).

\subsubsection{Des-Cubierta Cave and Ocelado Rockshelter}

Des-Cubierta Cave was first excavated in 2009 and is under study (BAQUEDANO et al. 2014). This site, on top of the Calvero de la Higuera, will allow to complete the knowledge we have about the life and ecology of Neanderthals and mammals (both carnivores and herbivores) in the Upper Lozoya valley during the Pleistocene and to understand how they shared the territory.

To finish, Ocelado Rockshelter, also a small gallery of phreatic origin, has yielded only faunal remains and seems to be a den.

\section{THE PROJECT}

The Ph.D. project in Archaeology started late 2012, under the direction of Nuno Bicho, University of Algarve, with co-direction of Enrique Baquedano, director of the Museo Arqueológico Regional de la Comunidad de Madrid and co-director of the excavations in Pinilla del Valle. The aim of this project is to study the lithic raw materials procurement strategies of the Mousterian assemblages from the Middle Palaeolithic sites of Pinilla del Valle.

The study of raw materials aims to determine the origin and the proportions of different types of raw material, present or absent in an archaeological site (GENESTE 1989; TURQ 2003; MEIGNEN et al. 2009; ANDREWSKY 2009; AUBRY et al. 2009). The case of Pinilla del Valle sites proves to be particular due to the following factors: i) geographic centrality in the Iberian Peninsula, ii) large variety of existing raw materials.

From the total of the seven sites identified so far in Pinilla del Valle, three of them - Navalmaíllo Rockshelter, Buena Pinta Cave and DesCubierta Cave - have important Mousterian lithic assemblages, characteristic of the Homo neanderthalensis populations. These assemblages are being studied under various perspectives - use wear analysis, technological aspects and raw materials (MÁRQUEZ et al. 2013).

The raw material procurement study can be divided into two phases. These phases and the following methodology will be applied to each site under study.

The first phase has been developed in the Museo Arqueológico Regional de la Comunidad de Madrid where the artefacts are deposited - the main objectives are: i) to define the materials present in the different assemblages, ii) to define the materials present in the archaeological context that do not appear in the region, iii) conduct direct surveys on the ground in different areas of influence and iv) to compare samples of archaeological collection with samples collected on geological surveys and define the groups that are present in the assemblages. 
The second phase will comprise the petrographic and geochemical analyses in a laboratory yet to choose depending on time, costs and quality of the available equipment. In this article we will only centre on the mains questions and methodology of the first phase of the project.

\subsection{The lithic assemblage of Pinilla del Valle}

The three archaeological sites of Pinilla del Valle comprised in this study - Navalmaíllo Rockshelter, Buena Pinta Cave and Des-Cubierta Cave - have an important set of Mousterian lithic industries. However, each site has its own characteristics, distinct functions and represent the Neanderthal occupation of the Lozoya Valley. Camino Cave is a hyena den with only some lithic pieces, probably displaced from its original context (ARSUAGA et al. 2012) and so it will not be considered in this study.

The Navalmaíllo Rockshelter has an assemblage of 14.684 pieces from the 2002 to 2012 field work and is the best collection studied so far (MÁRQUEZ et al. 2013; BAQUEDANO et al. 2014). The technological study concluded that the Mousterian lithics from Navalmaíllo Rockshelter are generally small in size as "some of the cores had been worked to a very small size; their products were therefore small as well" (MÁRQUEZ et al. 2013:389). Use wear on this same set is under study. As of 2008 B. MARQuEz (2013) differentiated fifteen types of raw materials from levels D and $F$ "although just six (quartz, chert, quartzite, porphyry, rock crystal, and sandstone) make up $90 \%$ of the total. Indeed, $77 \%$ of the artefacts are made of quartz, the most commonly used material" (MÁRQUEZ et al. 2013:379). The predominance of quartz based industry is an important feature that distinguishes this set from the ones of other sites in the centre of the Iberian Peninsula with the same chronologies (MÁRQUEZ et al. 2013). Most of these materials could be collected on the stream banks of Valmaíllo, Lontanar and Lozoya Rivers that carry rounded and subrounded porphyry, metamorphic quartzites, and granitoids cobbles and pebbles. "No chert is present in any of these fluvial networks, nor has any been found in the Cretaceous carbonate facies around the site" (MÁRQUEZ et al. 2013: 379). The identification of the possible sources of this material is one of the main objectives for the on going study.

Buena Pinta Cave has an assemblage of 436 pieces from excavations from years 2003 to 2012 where quartz is the preferred and most common raw material on both levels ( 5 and 23) that have the strongest presence of human activities (BAQUEDANO et al. 2014). There are no publications concerning the lithic assemblages from DesCubierta Cave, as they are still being studied.

\subsection{Methodology}

The raw material of the mentioned sites, excavated since 2002 to date, is being revised and studied according to each site and archaeological level. The materials present at each site and level are defined looking for patterns, similarities and differences in the various detected occupational levels.

At the moment the team are analysing and characterizing the different rock types macroscopically with the aid of a low resolution binocular microscope while detail photographs have been obtained at the laboratory of the Museo $A r$ queológico Regional de la Comunidad de Madrid. This builds a primary database of different materials present in the assemblage. In parallel, it has been made a selection of samples that can be analysed with petrographic methods and archaeometric techniques in the near future at CENIEH Centro Nacional de Investigación sobre la Evolución Humana (Burgos).

The Navalmaíllo site will be the first to analyse since it is the one with the greatest amount of Mousterian artefacts and it undoubtedly testifies a continued presence of Neanderthals in the rockshelter (ARSUAGA et al. 2011; BAQUEDANO et al. 2010, 2014; MÁRQUEZ et al. 2013). Artefacts from each year were selected for studio and binocular microscope photography. The criteria for the choices made were the following: i) representation of the raw material within the assemblage per year; ii) conservation status.

The studio photographs were performed at the Museo Arqueológico Regional de la Comunidad de Madrid, to register macroscopically the surface of the selected pieces. Then, photographs were taken in different magnifications $(10 \mathrm{x}, 40 \mathrm{x}$ and $80 \mathrm{x}$ ) with a binocular microscope model Olympus SZX12 with a digital camera attached and connected to a computer. This record was made in order to search for irregularities or peculiarities that might allow an easily differentiate raw materials in the future, to define them better and compare with possible sources. Until now, photos with the binocular microscope were taken to pieces from year 2004 to 2009 .

Surveys are being planned to known sites that already have geologic studies. The objective is to confirm the location of these possible sources and collect samples to compare with archaeological pieces. There are publications on the local geology of Madrid region and in the first phase of the project they will be useful to make comparisons with archaeological samples, saving time and resources (BUSTILlO et al. 2012; PÉREZ-JIMÉNEZ 2010).

All pieces are weighted and characterized, separated into preliminary groups to be further on studied with more detail. With this methodology we want to know not only the number of pieces of 
each type of raw material but also their total weight in relation to the collection to better understand the strategies of exploitation by archaeological level.

Despite not being able to display statistical data since the study is at a preliminary stage, we are able to make some notes about the nature of present raw-materials. Quartz is the most abundant raw material but also present are sandstones, flint, chert, quartzites and other metamorphic rocks are also present in considerable variety, although in smaller quantities.

\section{DISCUSSION}

The Iberian Peninsula is rich in traces of Neanderthal occupations, especially in peripheral areas. The possibility of studying this central region enables a global view of the strategies and characteristics of the areas of exploitation of the territory by Homo neanderthalensis. The study of the origin of different raw materials from Pinilla del Valle will allow the construction of interpretative models of territorial occupation and exploitation of resources in the Iberian Peninsula.

Navalmaillo Rockshelter is an habitation area with the presence of all elements that prove the presence of Neanderthals - Mousterian industry, hearths and bones with signs of manipulations as is the evidence of cut marks. The studied and published caves - Camino and Buena Pinta were hyena dens with the possibility of temporary Neanderthal occupations (Buena Pinta Cave) from the presence of few lithic instruments and cut marks on animal bones. By having different sites with clear different functions it is possible to study if there is a difference in the raw-materials found not just on each level but also in each site.

In a first general analysis of the assemblages of Navalmaíllo Rockshelter, there seems to be a specific human adaptation with the raw material used to knap different products and instruments by the action of previous and careful selection. We will try to verify if there is a relation between the reduction strategies and technological sequences (under study by the current Pinilla del Valle Research Team) and the raw materials and thus to understand how they can be influenced each other.

The aim is to have a better understanding of the technological and cultural behaviour of Peninsular Neanderthal population.The analysis and study of adaptation of techniques and the understanding of exploration and occupation strategies of the territory in relation to the available resources are essential to the study of these populations and their prevalence in the Iberian Peninsula.

\section{ACKNOWLEDGEMENTS}

Ana Abrunhosa expresses her gratitude to both Fundación Universidad de Alcalá de Henares and to Casa de Velázquez (Madrid) for respectiv- elly a two month grant in 2013 and a one month grant (specific aid for foreigners) in 2014. Authors would like to thank Jadranka Verdonkschot for the english language review.

\section{REFERENCES}

AlfÉreZ, F.; Molero, G.; MaldonAdo, E.; Bustos, V.; BreA, P. \& Buttrago, M.1982. Descubrimiento del primer yacimiento cuaternario (Riss-Würm) de vertebrados con restos humanos en la provincia de Madrid (Pinilla del Valle). Coloquios de Paleontología 37: 15-32.

AlfÉREZ, F. \& ROLDÁN, B. 1992. Un molar humano Anteneandertal con patología traumática procedente del yacimiento cuaternatio de Pinilla del Valle (Madrid). Munibe (Antropologia-Arkeologia). Supl. 8: 183-188.

Álvarez-Lao, D.J.; Arsuaga, J.L.; Baquedano, E. \& PÉREZ-GONZÁleZ, A. 2013. Last Interglacial (MIS 5) ungulate assemblage from the Central Iberian Peninsula: The Camino Cave (Pinilla del Valle, Madrid, Spain). Palaeogeography, Palaeoclimatology, Palaeoecology. 374: 327-337.

ANDREFSKY, W. 2009. Lithics: Macroscopic Approaches to Analysis. Cambridge Manuals in Archaeology. $2^{\text {nd. }}$ edition. Cambridge University Press.

Aubry, T.; Mangado Llach, X.; SAMPaIO, J.D.; CAlVo Trias, M.; IgreJa, M.A.; Klaric, L. \& GAMEIRO, C. 2009. 5.1.1. Estudo do aprovisionamento em matériasprimas. 200 Séculos da História do Vale do Côa: incursões na vida quotidiana dos caçadores-artistas do Paleolítico. Trabalhos de Arqueologia 52: 131-169.

Arsuaga, J.L.; Baquedano, E.; Pérez-GonZÁlez, A.; SAla Burgos, M.T.N.; García, N.; Álvarez-LaO, D.; Laplana Conesa, C.; Huguet, R.; SeVIlla García, P.; Blain, H.A.; QuAM, R.; RUIZ ZaPATA, M.B.; SALA, P.; GIL García, M.J.; UzQUíano Ollero, P. \& PANTOJA PÉREZ, A. 2010. El yacimiento kárstico del pleistoceno superior de la Cueva del Camino en el Calvero de la Higuera (Pinilla del Valle, Madrid). In Enrique Baquedano y Jordi Rosell (eds), Actas de la $1^{a}$ Reunión de Científcos sobre Cubiles de Hiena (y otros grandes carnivoros) en los Yacimientos Arqueológicos de la Península Ibérica (Zona Arqueológica 13). Alcalá de Henares, Museo Arqueológico Nacional: 349-368.

Arsuaga, J.L.; BAQuedanO, E. \& PÉREZ-GonZÁlez, A. 2011. Neanderthal and carnivore occupations in Pinilla del Valle sites (Community of Madrid, Spain). X UISPP Congress Proceedings - Lisbon. 2006. British Archaeological Reports International Series 2224,47: 111-119.

Arsuaga, J. L.; Baquedano, E.; PÉreZ-GonzÁlez, A. SAla, N.; QUAM, R.; RoDRÍGUEZ, L.; GARCÍA, R.; GARCÍA N.; Álvarez-Lao, D.; laplana, C.; Huguet, R. Sevilla, P.; Maldonado, E.; Blain, H.-A.; Ruiz ZAPATA, M.B.; SALA, P.; GIL-GARCÍA, M.J.; UzQuiano, P.; PANTOJA, \& MÁrQueZ, B. 2012 Understanding the ancient habitats of the lastinterglacial (late MIS 5) Neanderthals of central Iberia: Paleoenvironmental and taphonomic evidence from the Cueva del Camino (Spain) site. Quaternary International, 275: 55-75.

Baquedano, E.; Arsuaga, J.L. \& PÉREZ-GonZÁlez, A. 2010. Homínidos y carnívoros: competencia en un mismo nicho ecológico pleistoceno: los yacimientos del Calvero de la Higuera en Pinilla del Valle. Actas de las Quintas Jornadas de Patrimonio Arqueológico en la Comunidad de Madrid: 61-72. 
Baquedano, E.; MÁRQuez, B.; Pérez-González, A.; MosqueRA, M.; Huguet, R.; ESPINOSA, J.A.; SÁNCHEZRomero, L.; PANera, J. \& Arsuaga, J.L. 2014. Los Neanderthales en el Valle del Lozoya: Los yacimientos paleolíticos del Calvero de la Higuera (Pinilla del Valle, Madrid). Mainake 32: 83-100.

Bellido, F.; Escuder, J.; Klein, E. \& Del Olmo, A. 1991. Mapa Geológico de España a E. 1:50.000. Buitrago del Lozoya (484). Madrid, IGME.

Bustillo, M.A.; Pérez-Jiménez, J.L. \& Bustillo, M. 2012. Caracterización geoquímica de rocas sedimentarias formadas por silicificación como fuentes de suministro de utensilios líticos (Mioceno, cuenca de Madrid). Revista Mexicana de Ciencias Geológicas, Vol. 29, 1: 233-247.

FERNÁNDEZ-Lomana, C.D. 1993. Estudio tafonómico de los macrovertebrados de yacimientos del Pleistoceno Medio. Complutum, 4: 21-40.

Finlayson, C.; Giles Pacheco, F.; Rodríguez-Vidal, J.; Fal, D.A.; Gutierrez LóPez, J.M.; SANTIAGo Pérez, A. Finlayson, G.; Allue, E.; Baena Preysler, J.; CÁceRES, I.; CARRIÓN, J.S.; FERNÁNDEZ JALVO, Y.; GLEEDOWEN, C.P.; JIMENEZ ESPEJO, F.J.; LÓPEZ, P.; LÓPEZ SÁEZ, J.A.; Riquelme Cantal, J.A.; SÁNChEZ MarCo, A.; Giles GuzMan, F.; Brown, K.; Fuentes, N.; ValaRINO, C. A.; VIlLalPando, A.; Stringer, C.B.; MartiNEZ RUIZ, F.; \& SAKAMOTO, T. 2006. Late survival of Neanderthals at the southernmost extreme of Europe. Nature, 443: 850-853.

GENESTE, J.M. 1985. Analyse lithique d'industries moustériennes du Périgord: une approche technologique du comportement des groupes humains du Paléolithique moyen. Thèse Sc., Bordeaux I.

MANGADO, J. 2006. El aprovisionamiento en materias primas líticas: hacia una caracterización paleocultura de los comportamientos paleoeconómicos. Trabajos de Prehistoria, Vol. 63, 2: 79-71.

MÁRQUeZ, B.; MosquerA, M.; BAQUEDANO, E.; PÉREZ-GONZÁLEZ A.; ARSUAGA, J.L.; PANERA, J.; ESPINOSA, J. A. \& GÓMEZ J. 2013.Evidence of a Neanderthal-made quartz-based technology at Navalmaíllo rockshelter (Pinilla del Valle, Madrid Region, Spain). Journal of Anthropological Research, 69(3): 373-395.

Meignen, L.; Delagnes, A.; Bourguignon, L. 2009. Patterns of lithic material procurement and transformation during the middle Paleolithic in Western Europe In Adams B. Blades B.S. (eds) Lithic Materials and Paleolithic Societies. Blackwell Publishing.
PEREIRA, T. 2013. Reasons for raw material patterns in south western iberia. In A. Pastors and B.(Auffermann eds). Pleistocene foragers on the Iberian Peninsula: their culture and environment. Festschrift in honour of Gerd-Christian Weniger for his sixtieth birthday. Wissenschaftliche Schriften des Neanderthal Museums 7: 143-161.

Pereira, T., Haws, J. \& Bicho, N. 2014. O Paleolítico Médio no Território Português. Mainake. 33: 11-30.

PéreZ-GonZÁlez, A.; Karampaglidis, T.; Arsuaga, J.L.; Baquedano, E.; BÁrez, S.; Gómez, J.J.; PANERA, J.; Márquez, B.; Laplana, C.; Mosquera, M.; Huguet, R.; Sala, P.; ArRiaza, M.C.; Benito, A., ARACIL, E. \& MALDONADO, E. 2010. Aproximación geomorfológica a los yacimientos del Pleistoceno Superior del Calvero de la Higuera en el Valle Alto del Lozoya (Sistema Central Español, Madrid). In Enrique Baquedano y Jordi Rosell (eds), Actas de la $1^{a}$ Reunión de Científicos sobre Cubiles de Hiena (y otros grandes carnivoros) en los Yacimientos Arqueológicos de la Península Ibérica (Zona Arqueológica 13). Alcalá de Henares, Museo Arqueológico Nacional: $404-420$

PÉREZ JiMÉNEZ, J.L. 2010. Sedimentología, silicificaciones y otros procesos diagenéticos en las unidades intermedia y superior del Mioceno de la Cuenca de Madrid (zonas $N E, N W y W$ ). Ph.D. thesis. Universidad Complutense de Madrid.

Ruiz Zapata, M.B.; Gómez GonZÁlez, C.; Gil García, M.J.; PÉrez GonZÁlez A.; LóPeZ-SÁeZ, J.A.; ARSUAGA, J.L. \& BAQUEDANO, E. 2008. Evolución de la vegetación durante el Pleistocenosuperior y el Holoceno en el valle alto del río Lozoya. Yacimiento arqueopaleontológico de la cueva de la Buena Pinta (Pinilla delValle. Sistema Central Español). Geogaceta. 44: 83-86.

Torre, I.; MartíneZ-Moreno, J. \& Mora, R. 2014. Change and Stasis in the Iberian Middle Paleolithic: Considerations on the Significance of Mousterian technological variability. Current-Anthropology, Vol. 54, Supplement 8: 320-336.

TURC, A. 2003. De la matière première lithique brute à la mise au jour de l'object archéologique : propositions pour une meilleure exploitation du potentiel informatif du matériel lithique illustrées par quelques exemples du Paléolithique aquitain. Habilitation à diriger des recherches, Université de Perpignan.

VERA J.A. (ed). 2004. Geología de España. Madrid, SGEIGME. 